\title{
WEAR BEHAVIOR OF HYBRID COMPOSITE REINFORCED WITH TITANIUM DIOXIDE NANOPARTICLES
}

\author{
Meshref A. A., MazenA. A., El-Giushi M. A. and Ali W. Y. \\ Department of Production Engineering \& Design, Faculty of Engineering, \\ Minia University, EGYPT.
}

\begin{abstract}
The aim of the present study is to investigate the influence of polymerization times, normal loads and titanium dioxide nanoparticles content on the wear of hybrid composite resin reinforced with titanium dioxide $\left(\mathrm{TiO}_{2}\right)$ nanoparticle. The materials used are hybrid composite resin and titanium dioxide nanoparticles $\left(\mathrm{TiO}_{2}\right.$ nanoparticles). Four groups of composite resin samples are prepared; one as received and three groups reinforced with $\mathrm{TiO}_{2}$ nanoparticles in contents of $0.1,0.2$ and 0.3 wt. \%. Hybrid composites resin is manually mixed with $\mathrm{TiO}_{2}$ nanoparticles. The resulting blend is packed into plastic cylindrical bars. The samples are then cured from both sides for 10, 20, 40, 60 and 80 seconds using a visible light curing unit. To determine the wear, all samples are tested with two-body abrasion, reciprocating sliding apparatus at room temperature. The test conditions are; sliding velocity $=60$ strokes $/ \mathrm{min}$, load $=$ $6,8,10,12$ and $14 \mathrm{~N}$, time $=60$ seconds. Results show that the wear decreases with the increase of polymerization time at all normal loads. Results showed also that wear depends on the normal load. The wear initially decreased and reached a minimum at a concentration of $0.1 \mathrm{wt} . \% \mathrm{TiO}_{2}$ nanoparticles, above $0.1 \mathrm{wt}$. $\% \mathrm{TiO}_{2}$ nanoparticles, the aggregation of $\mathrm{TiO}_{2}$ nanoparticles led to increase of the wear. The present study suggests that in order to minimize wear, it is important to use relatively higher polymerization time, lower $\mathrm{TiO}_{2}$ content and lower force of chewing.
\end{abstract}

Keywords: Polymerization time, dental nanocomposite, wear, titanium dioxide, nanoparticles, hybrid composite resin, normal load.

\section{INTRODUCTION}

Dental composite restorative materials are made of a highly cross linked dimethacrylate resin strengthened with silanated inorganic filler particles (about 50 vol. \%) [1]. Composite resins gain more importance and popularity for the restoration of all cavity classes because of their excellent aesthetic properties. However, clinically, their comparatively poor wear resistance is still considered as a factor that participates to materials' failure [2]. Wear appears as a surface damage or elimination of material from one or both sides of solid surfaces that are in contact during motion. In most cases, wear happens by surface interactions on the surface non uniformity [3]. Wear resistance is very significant to dental composite resins, specially when being used in heavily loaded regions. Failure rates are higher for larger restorations, and may still be an important mode of failure for patients with bruxism and clenching customs. Therefore, discussing the friction and wear behavior is of pivotal importance to the advance of dental material development [4]. 
Refinements of mechanical properties of the composite materials have permitted its use in posterior teeth with greater reliability than was the case some years ago. These refinements included; development of smaller particle sizes of filler, better bonding systems, curing improvements and sealing systems [5]. Ayman et al., [6], concluded that the change of wear resistance depends on the size and volume fraction of the nanofilling materials.

The main parameters affecting the wear are shown in Fig. 1. The contact temperature has an important effect on the wear resistance [7]. Abrasive wear would rise as the temperature increases, because the hardness and yield strength decrease [8].

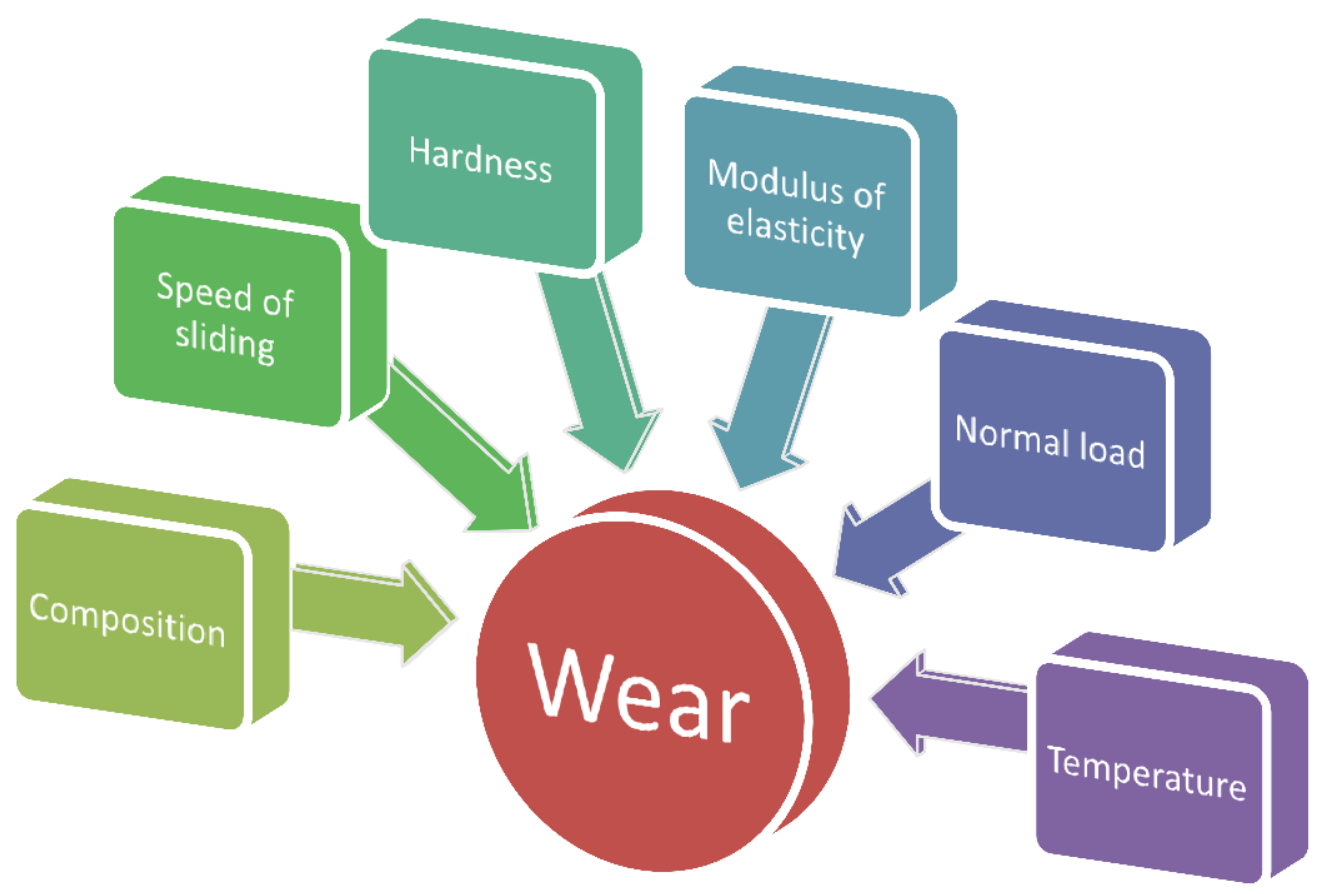

Fig. 1. Main factors affecting the wear behavior.

The normal load affects strongly the wear rate. Wear rate increases with the increase in normal load for glass fiber, PTFE and nylon. The shear force and frictional thrust also increase with the increase in applied load and these increments accelerate the wear rate [9]. The rate of abrasive wear was found to increase slightly with the rise in sliding speed in the range from 0 to $2.5 \mathrm{~m} / \mathrm{s}$ ( 0 to $8.2 \mathrm{ft} / \mathrm{s})$. This rise in wear may be attributed to frictional heating [8]. It was found that the mechanical wear of teeth increased with increasing the velocity of brushing due to the accelerated motion of abrasive particles $[10,11]$. Modulus of elasticity describes stiffness, a measure of the resistance to deformation under load of the material, with a high number indicating greater stiffness [12]. Also the composition of the materials has an important influence on the wear behavior. Aljosa et al., [13], illustrated that the inorganic filler type and concentration have the major effect on the mechanical behavior of the composites. Filler particles dimensions have been changed and decreased over the years, down to the nanodimension, in order to develop better material properties. Nanoparticles have high surface area and unparalleled physicochemical characteristics, and they 
can influence the overall bulk material lineaments. Further, high inorganic filler content reduces the volume of the organic matrix that causes unfavorable material characteristics, such as: low wear resistance, low mechanical strength, polymerization contraction, high coefficient of thermal expansion, etc.

Several studies have examined the influence of normal load and titanium dioxide nanoparticles weight percent on wear resistance. Manhart et al., [14], found that the wear resistance of composite resins significantly improved with increased filler loading and with decreased average filler particle size. Higher wear rates are related to the larger filler particles in the composite materials. Agarwal et al., [15], revealed that wear rate increases with the increase in the value of normal load of $\mathrm{SiC}$ filled chopped glass fiber reinforced epoxy composite. Ramadan et al., [16], showed that wear of acrylic tooth slightly increased with increasing the normal load. At a normal load of $3 \mathrm{~N}$ the mechanical wear reached 16.6 $\mathrm{mg}$. This value increased to $22 \mathrm{mg}$ at normal load of $5 \mathrm{~N}$. Chang et al. [17] studied the influence of $\mathrm{TiO}_{2}$ nanoparticles on short fiber reinforced epoxy under various loading conditions. They found that the addition of 5 vol. $\%$ of titanium dioxide nanoparticles could significantly decrease the wear rate of epoxy composites than padding only by conventional fillers.

The goal of the present work is to study the effect of polymerization times, normal loads, and reinforcement weight percent on the wear behavior of dental hybrid composite resin filled with titanium dioxide nanoparticles.

\section{MATERIALS}

The materials used are hybrid composite resin of shade $\mathrm{A} 1$ and $\mathrm{TiO}_{2}$ nanoparticles of $25 \mathrm{~nm}$ diameter. Detailed information about the materials used in the present work is shown in Tables 1 and 2.

Table 1: Specifics of composite resin

\begin{tabular}{||c|c|c|c|c|c||}
\hline Description & Classification & Manufacturer & Shade & Curing & Lot no. \\
\hline \hline $\begin{array}{c}\text { Visible light cure, } \\
\text { Resin-based } \\
\text { dental restorative } \\
\text { material }\end{array}$ & Hybrid composite & Prime-Dent, U.S.A. & A1 & Light cure & YL08Q \\
\hline
\end{tabular}

Table 2: Specificsof $\mathrm{TiO}_{2}$ naoparticles

\begin{tabular}{|c|c|c||}
\hline Diameter & Density & Surface area \\
\hline \hline $21 \mathrm{~nm}$ & $4 \mathrm{~g} \mathrm{~cm}^{-3}$ & $50 \mathrm{~m}^{2} \mathrm{~g}^{-1}$ \\
\hline
\end{tabular}


Vol. 39, No. 1. January 2020

\section{EXPERIMENTAL METHODS}

In this study there are four experimental groups consisting of three hybrid composites resin containing $\mathrm{TiO}_{2}$ nanoparticles in different contents of $0.1,0.2$ and $0.3 \mathrm{wt} \%$ and one as received group, contained no $\mathrm{TiO}_{2}$ nanoparticles. The method of preparation of samples is illustrated in Ref. [18].The samples have cylindrical form with $6 \mathrm{~mm}$ diameter and $10 \mathrm{~mm}$ height as illustrated in Figs.2.

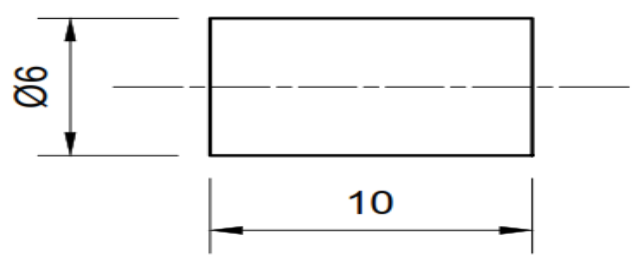

Dim. in mm

Fig.2 Dimensions of specimen.

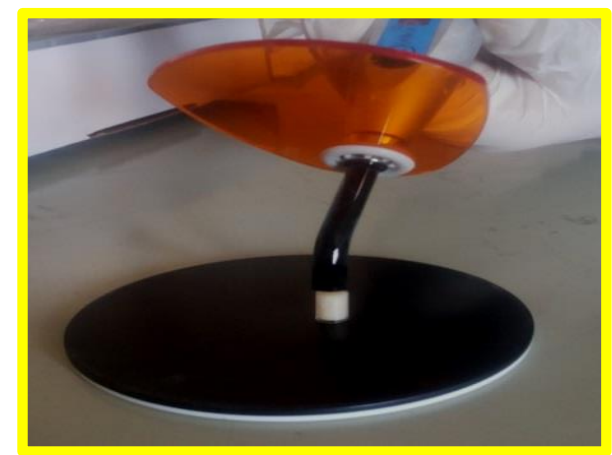

Fig.3 Polymerization of the samples by light emitting diode source

(LED).

\section{POLYMERIZATION OF SAMPLES}

The light source used in this research to polymerize samples is blue light emitting diode (LED). Figure 3 shows the polymerization of the samples by light emitting diode source. Specifications of the LED are shown in the Table 3. The light polymerization modes used in this research were as follows: gradually strong, flashing and strong mode.
Table 3: Specifications of the Light Emitting Diode (LED)

\begin{tabular}{|c|c|c|}
\hline $\begin{array}{c}\text { Intensity } \\
\left(\mathrm{mW}_{\mathbf{c m}}{ }^{2}\right)\end{array}$ & $\begin{array}{c}\text { Spectral emission } \\
(\mathrm{nm})\end{array}$ & Solidify time and depth \\
\hline $1200-2000$ & $420-480$ & $5 \mathrm{~s} / 3 \mathrm{~mm}$ \\
\hline \hline
\end{tabular}

\section{WEAR TEST}

To study the wear of the composite, cylindrical samples $(6 \mathrm{~mm}$ in diameter and $10 \mathrm{~mm}$ in length) of each condition were made in bars with $6 \mathrm{~mm}$ diameter and 10 $\mathrm{mm}$ height. Each sample is held stationary in a jig under different normal loads $(6,8,10$, 12 and $14 \mathrm{~N}$ ) against emery paper (1000 grit 
$0.0001 \mathrm{~g}$ accuracy. Figure 4 shows two-body abrasion, reciprocating sliding apparatus.

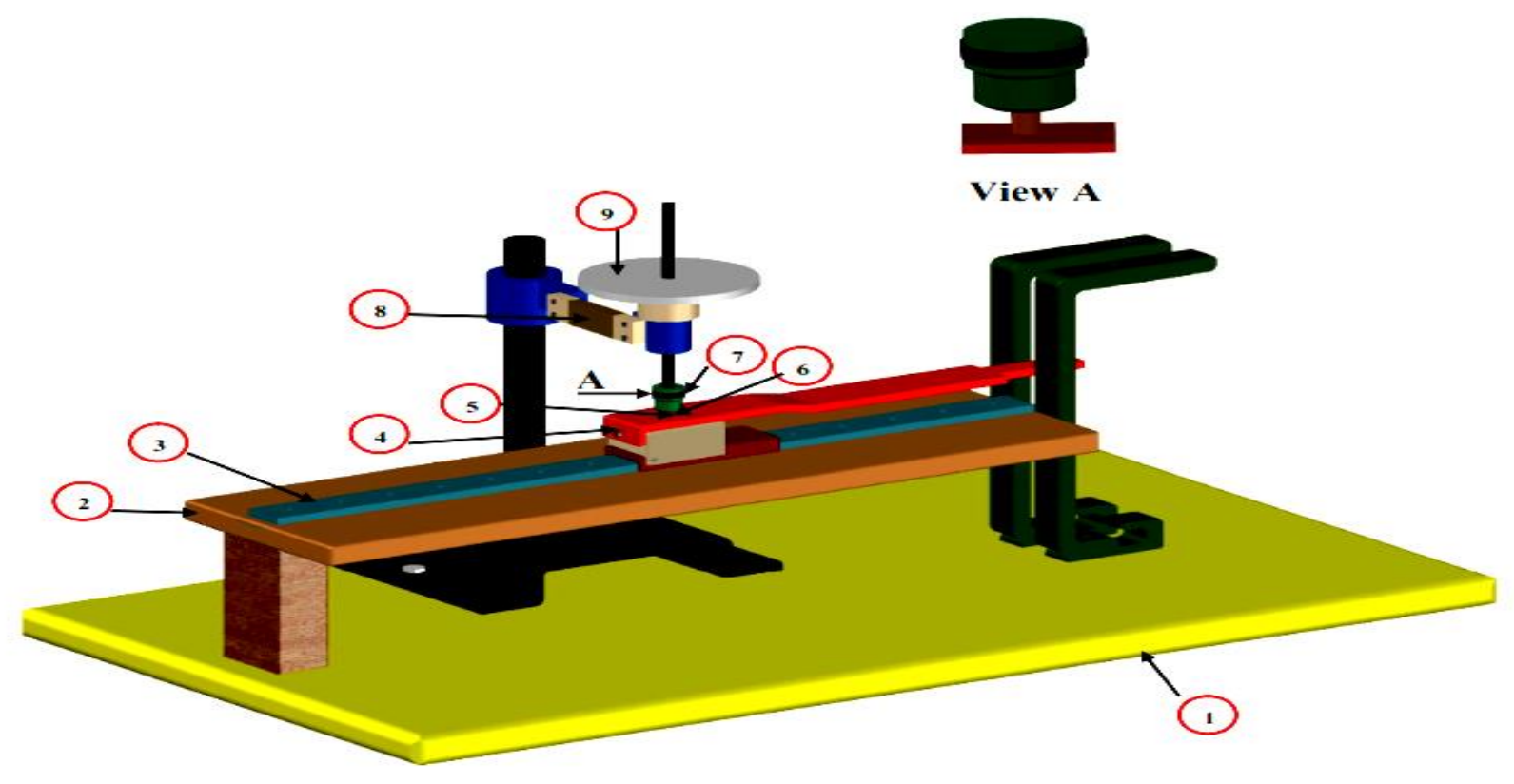

Fig. 4 Two-body abrasion, reciprocating sliding apparatus (1) Base plate (2) Plate (3) Linear bearing (4) Table (5) Emery paper (6) Test sample (7) Sample jig (8) Load cell (9) Normal load

\section{RESULTS AND DISCUSSION}

In order to investigate the influence of polymerization time, normal load and titanium dioxide nanoparticles content on the wear of tested samples, a series of experiments were carried out at various curing times, normal loads and titanium dioxide nanoparticles weight content. Wear versus polymerization time of the gradually strong mode, flashing mode and strong mode are shown in Figs. 5, 6 and 7, respectively, for as received samples. Figs.5, 6 and 7, revealed that wear decreases with increasing polymerization time at all normal loads used. The reason for the decrease in wear is attributed to increase the hardness [18]. As it is evident in Figs. 5, 6 and 7 the hybrid composite cured at $80 \mathrm{~s}$ exhibited the lowest wear followed by the hybrid composite cured at $60 \mathrm{~s}$, then the hybrid composite cured at $40 \mathrm{~s}$, then the hybrid composite cured at $20 \mathrm{~s}$ and lastly the hybrid composite cured at $10 \mathrm{~s}$. the hybrid composite cured at $80 \mathrm{~s}$ and the hybrid composite cured at $60 \mathrm{~s}$ are significantly better than the hybrid composite cured at 20 $\mathrm{s}$ and the hybrid composite cured at $10 \mathrm{~s}$.

The wear appears to depend on the normal load; as the normal load increases, the wear first increases, and then falls. The decrease in the wear at high normal loads may be due to the decrease in the sliding speed of the apparatus at the high normal loads, as the sliding speed decreases, the wear decreases. Fig. 5 shows that when the normal load is above $6 \mathrm{~N}$, the wear increases up to $8 \mathrm{~N}$. Above this load and up to about $14 \mathrm{~N}$, the wear decreases with increasing the normal load. As indicated in Fig. 5, the higher wear is produced by the normal load $8 \mathrm{~N}$, while 
Vol. 39, No. 1. January 2020

the low wear is produced by the normal load $14 \mathrm{~N}$.

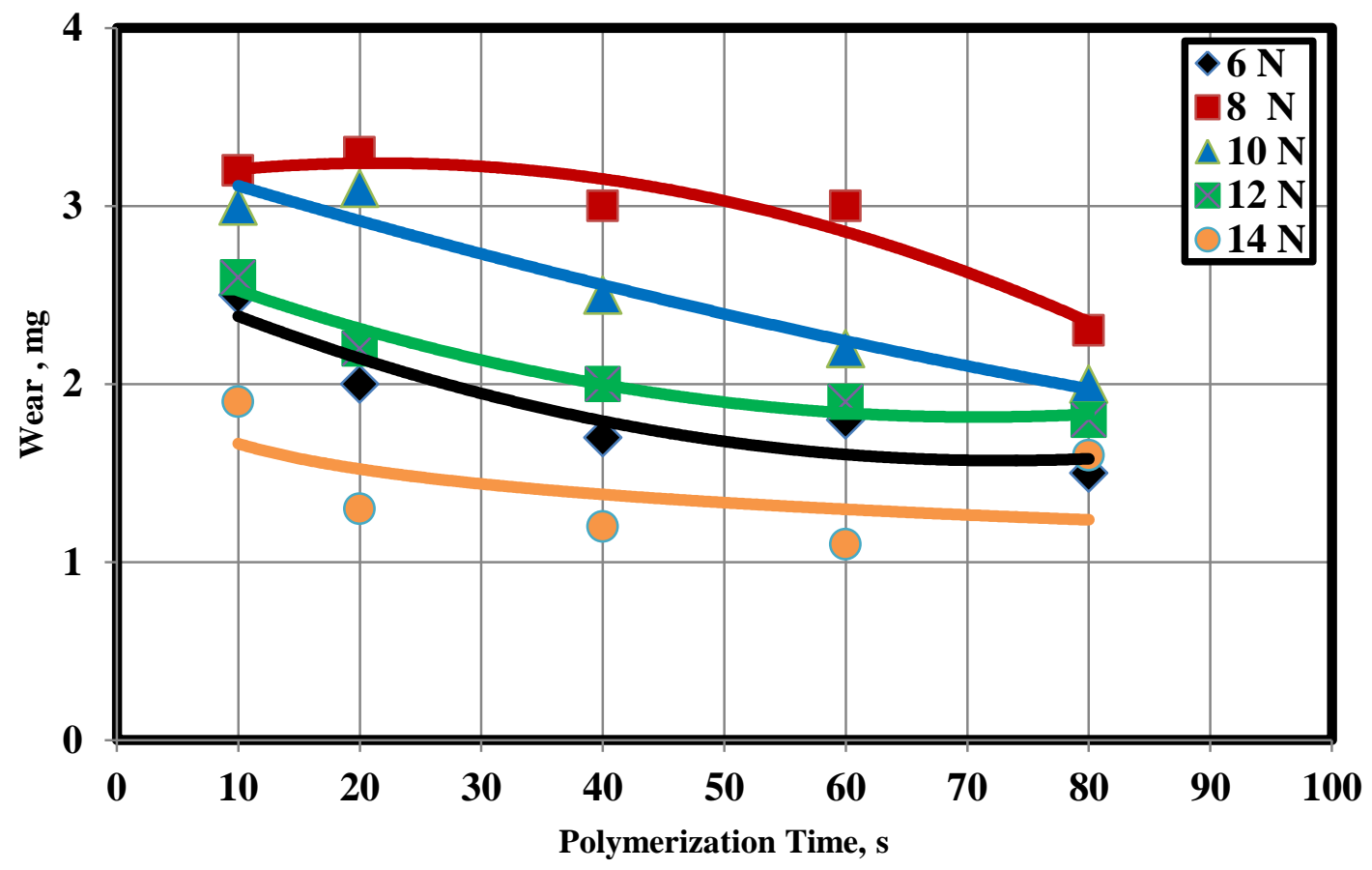

Fig. 5. Effect of polymerization time on wear for as received samples in gradually strong mode.

Also Figs. 6 and 7 show that when the normal load is above $6 \mathrm{~N}$, the wear increases with increasing the normal load up to $12 \mathrm{~N}$. Above this load up to about 14 $\mathrm{N}$, the wear decreases with increasing the normal load. The reason for the increase in the wear up to $12 \mathrm{~N}$ may be attributed to the increase in the contact area when the normal load is increased. As illustrated in Fig. 6, the higher wear is produced by the normal load $12 \mathrm{~N}$, while the low wear is produced by the normal load 14 N. Fig. 7 revealed that the highest value of the wear is observed in the normal load $12 \mathrm{~N}$, while the lowest value of the wear is observed in the normal load $6 \mathrm{~N}$. It observes from the results that the hybrid composite resin cured at $80 \mathrm{~s}$ gives the lowest value of the wear. For the gradually strong and flashing modes specimens, the normal load $14 \mathrm{~N}$ gives the lowest value of the wear, while for the strong mode specimens the normal load $6 \mathrm{~N}$ gives the lowest value of the wear. 
Vol. 39, No. 1. January 2020

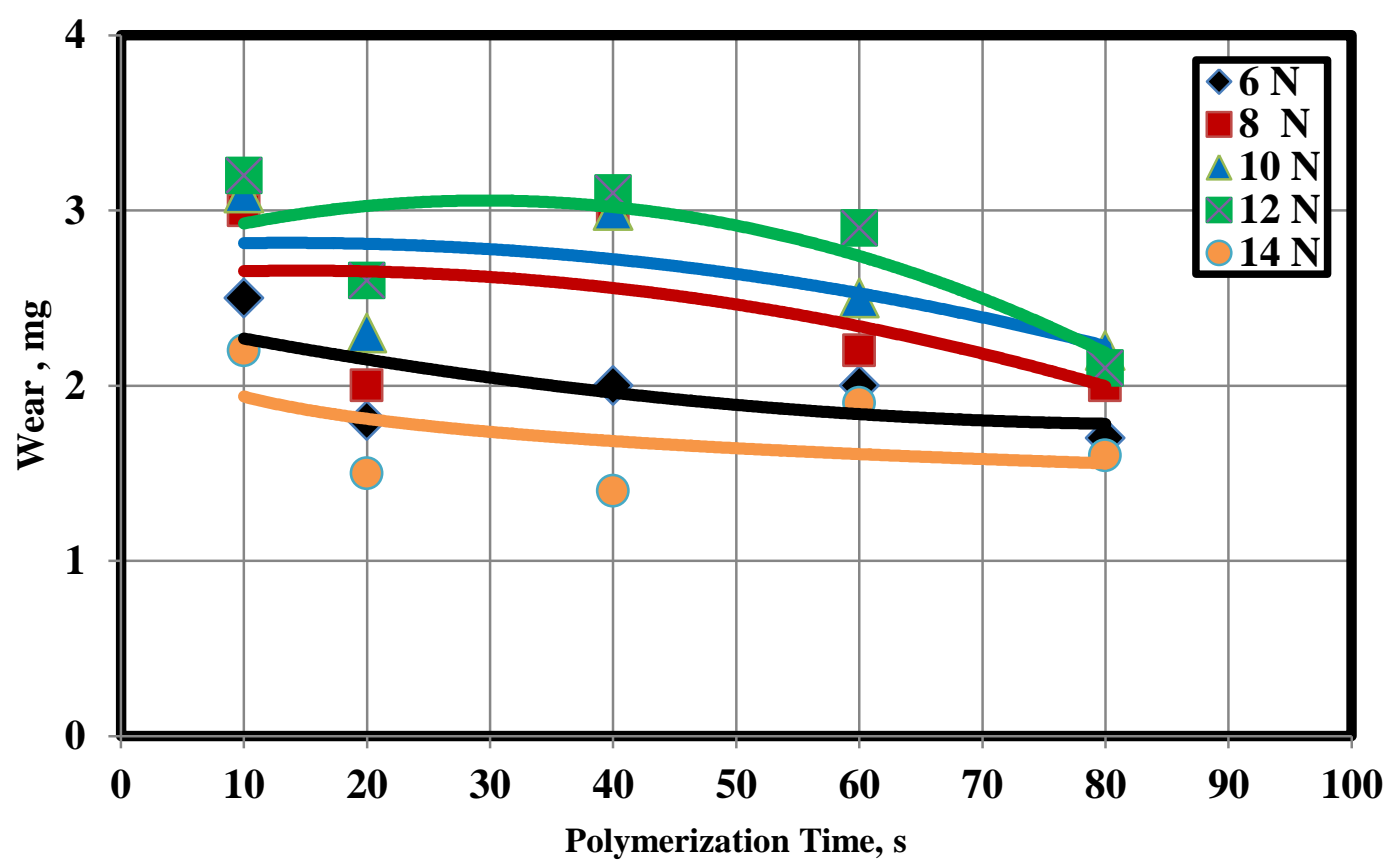

Fig. 6 Effect of polymerization time on wear for as received samples in flashing mode.

The effect of concentration of $\mathrm{TiO}_{2}$ nanoparticles on the wear of the hybrid composite resin cured with gradually strong, flashing and strong modes at various normal loads are displayed in Figs. 8, 9 and 10, respectively at 80 second polymerization time. It is evident that the wear first decrease when $\mathrm{TiO}_{2}$ NPs increased from 0 wt. $\%$ to 0.1 wt. $\%$ and then increase when $\mathrm{TiO}_{2}$ increased from $0.1 \mathrm{wt}$. $\%$ to $0.3 \mathrm{wt}$. \% for the three modes at all values of normal loads. The decrease in the wear up to $0.1 \mathrm{wt}$. $\%$ of $\mathrm{TiO}_{2} \mathrm{NPs}$ may be attributable to higher contact surface of nano fillers with the organic matrix, which leads to improve the material strength [19]. Therefore, the wear will decrease. The reason for the increase in wear after 0.1 wt. $\%$ of $\mathrm{TiO}_{2}$ may be attributed to an increment the concentration of $\mathrm{TiO}_{2}$ nanoparticles. The interface between nanoparticles and a polymer matrix can transfer stress, which is beneficial for the enhancement of the tensile strength of composite films. However, with increasing the concentration of nanoparticles, aggregation occurs, which leads to a decrease in the interaction between particles and polymer resulting in defects in the composites [20]. So the wear will increase. Fig. 8 revealed that the hybrid composite containing 0.1 wt. $\% \mathrm{TiO}_{2}$ nanoparticles exhibited the lowest wear value followed by the hybrid composite containing 0.2 wt. \% $\mathrm{TiO}_{2}$ nanoparticles, then the hybrid $\begin{array}{lllll}\text { composite containing } & 0 & \text { wt. } & \% & \mathrm{TiO}_{2}\end{array}$ nanoparticles and lastly the hybrid composite containing 0.3 wt. $\% \mathrm{TiO}_{2}$ nanoparticles. In other words, the hybrid composite containing 0.1 wt. $\% \mathrm{TiO}_{2}$ nanoparticles has a higher resistance to wear then the hybrid composite resin containing $0,0.2$ and 0.3 wt. $\% \mathrm{TiO}_{2}$ nanoparticles. 
Vol. 39, No. 1. January 2020

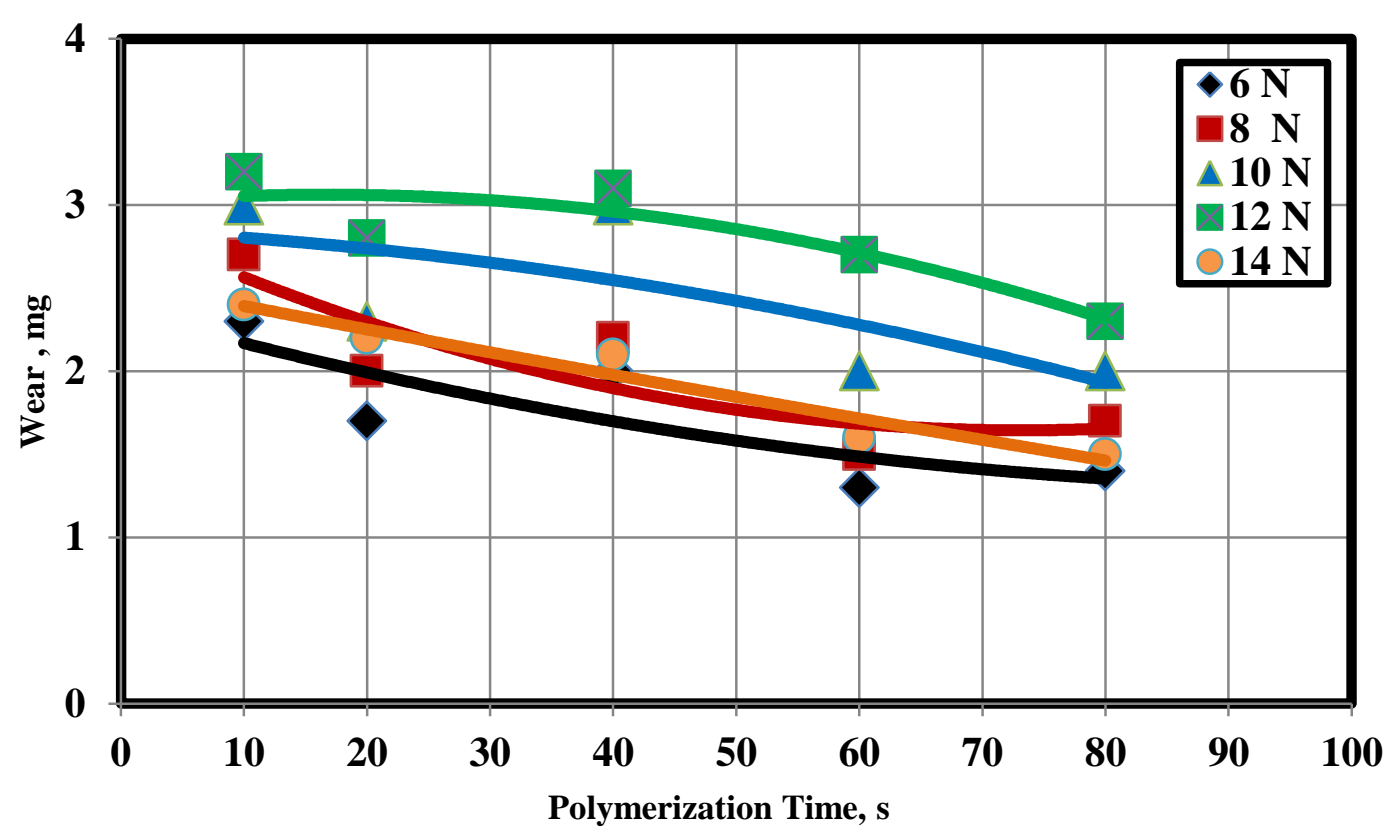

Fig. 7 Effect of polymerization time on wear for as received samples in strong mode.

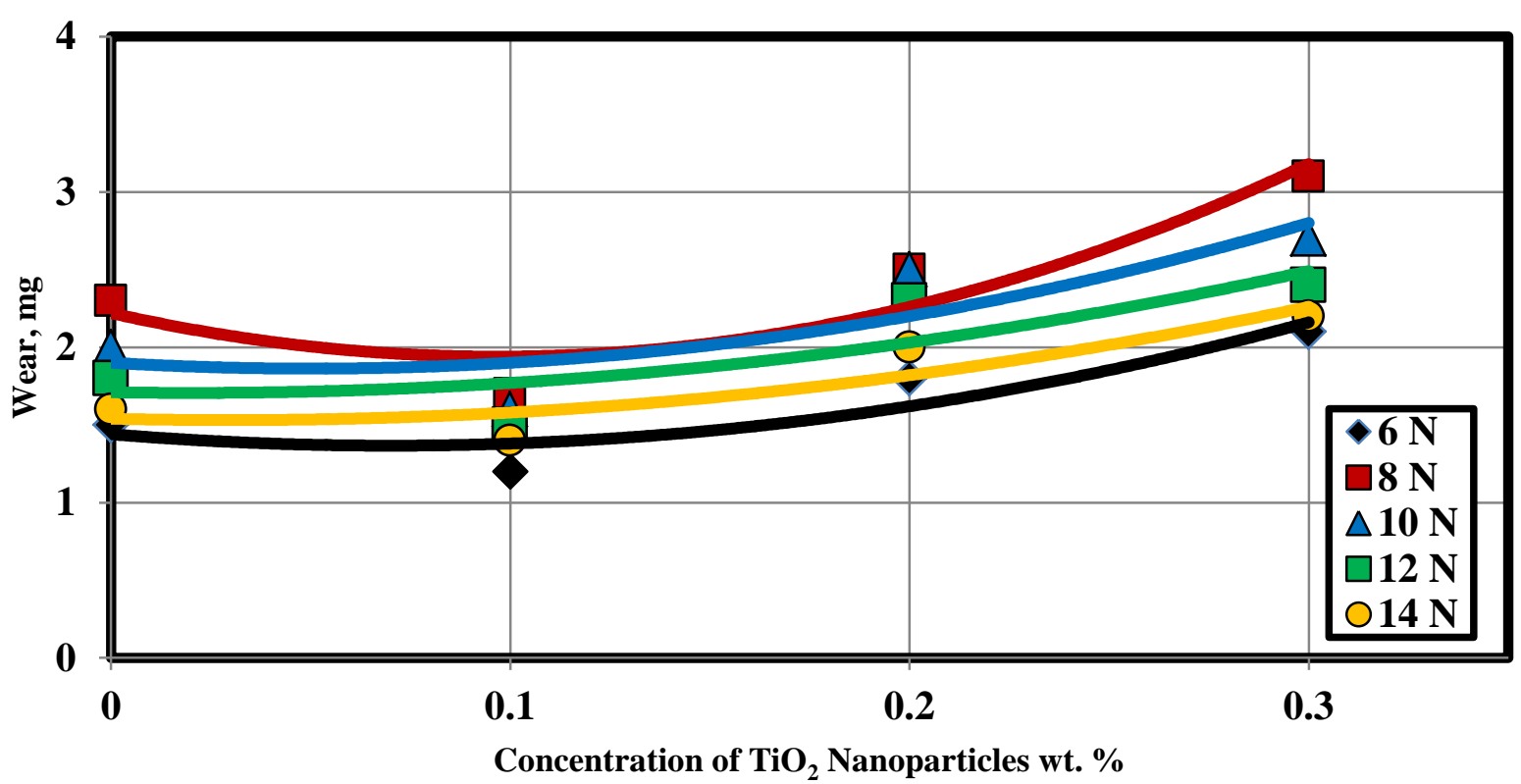

Fig. 8 Effect of concentration of $\mathrm{TiO}_{2}$ nanoparticles on wear of gradually strong mode samples at 80 second.

Regarding to the normal load, it is clear that the wear first increase then decreases with increasing normal load from 6 to $14 \mathrm{~N}$. the reason for this behavior was discussed in Fig. 5 page 7 . Figs. 8 shows that when the normal load is above $6 \mathrm{~N}$, the wear increases with increasing the normal load up to $8 \mathrm{~N}$. Above this load up to about $14 \mathrm{~N}$, the wear decreases with increasing the normal load. The wear is higher for the normal load $8 \mathrm{~N}$ followed by the normal load $10 \mathrm{~N}$, then the normal load $12 \mathrm{~N}$, then the normal load $14 \mathrm{~N}$ and lastly the normal load $6 \mathrm{~N}$. So the normal load $6 \mathrm{~N}$ has the 
highest resistance for wear. As shown in Figs. 9 and 10, the wear first increases when the normal load increased from $6 \mathrm{~N}$ to $10 \mathrm{~N}$ and then decrease when the normal load increased from $10 \mathrm{~N}$ to $14 \mathrm{~N}$. From Figs. 9 and 10 , it is clear that the normal load $6 \mathrm{~N}$ gives minimum wear, while the normal load $10 \mathrm{~N}$ gives maximum wear. These results demonstrate that wear resistance of the hybrid composite resin is improved remarkably by adding a small content of $\mathrm{TiO}_{2}$ and by using low normal load. This study suggests that in order to optimize wear, it is important to use high polymerization time, low content of $\mathrm{TiO}_{2}$ nanoparticles and low masticatory forces.

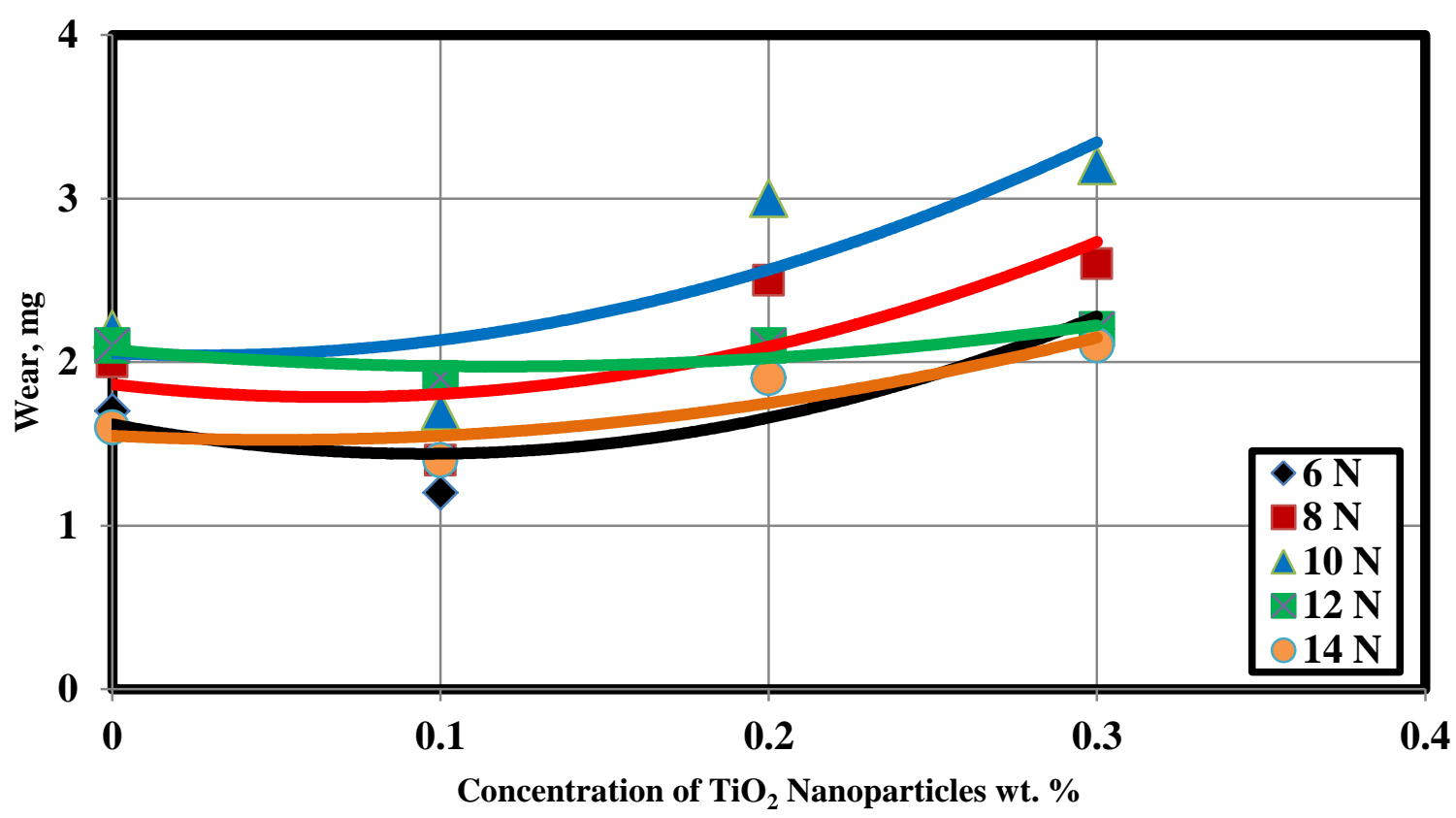

Fig. 9 Effect of concentration of $\mathrm{TiO}_{2}$ nanoparticles on the wear of flashing mode samples at 80 second.

\section{MICROSCOPIC EXAMINATION}

The surface of the hybrid composites was observed by optical microscope to study the effect of polymerization time on the surface morphology of the composite samples. Fig. 11 (a-e) shows the morphology of surfaces of strong mode light cured samples for as received condition at $10,20,40,60$ and 80 seconds polymerization time. From Fig. 11 (a-d), it is clear that the surface of samples contains white bubbles, while Fig. 11 (e) shows that the surface of sample has brown bubbles. Fig.11 (d) demonstrates presence of small particles of debris on the surface of sample. 
Vol. 39, No. 1. January 2020

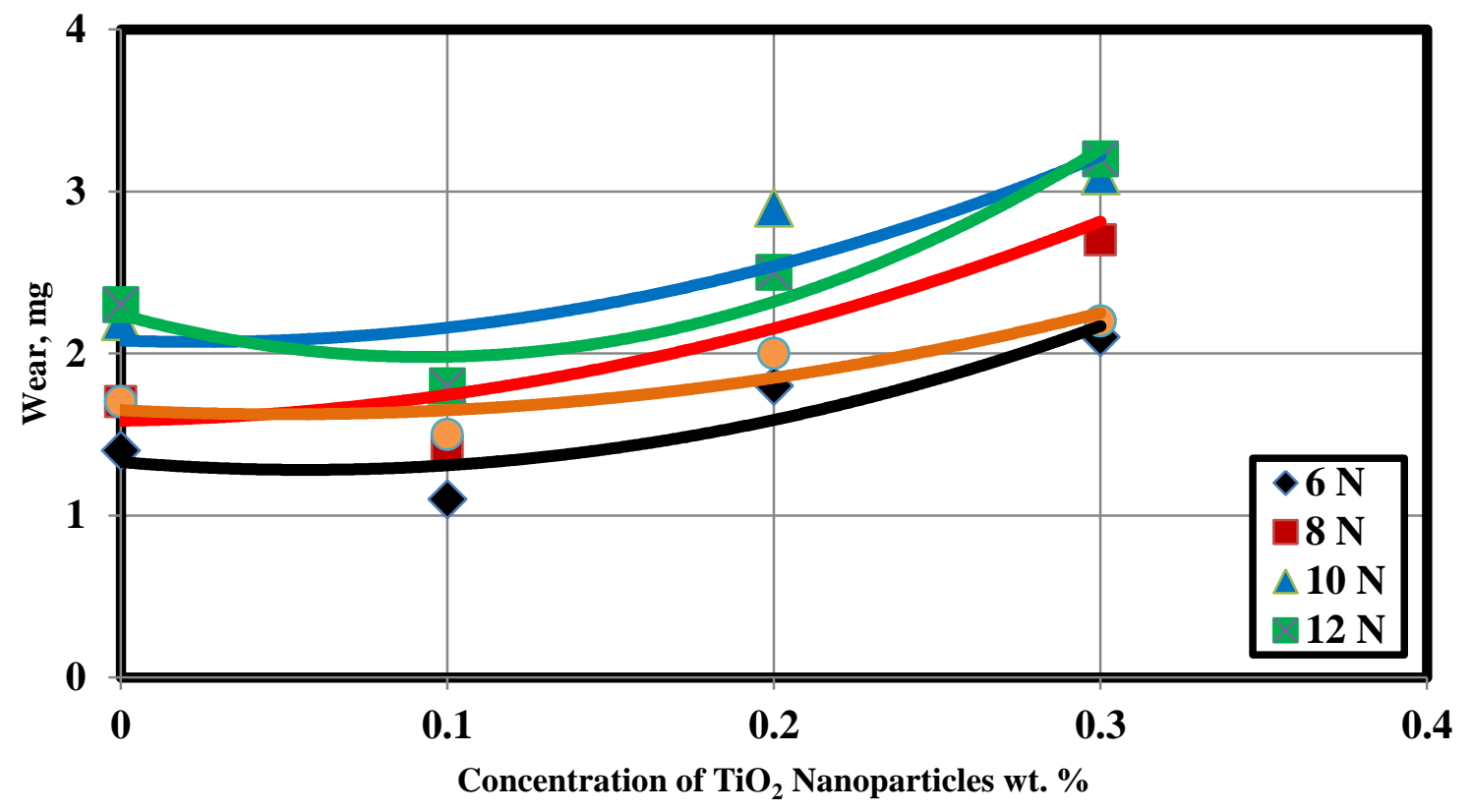

Fig. 10 Effect of concentration of $\mathrm{TiO}_{2}$ nanoparticles on the wear of strong mode samples at 80 second.
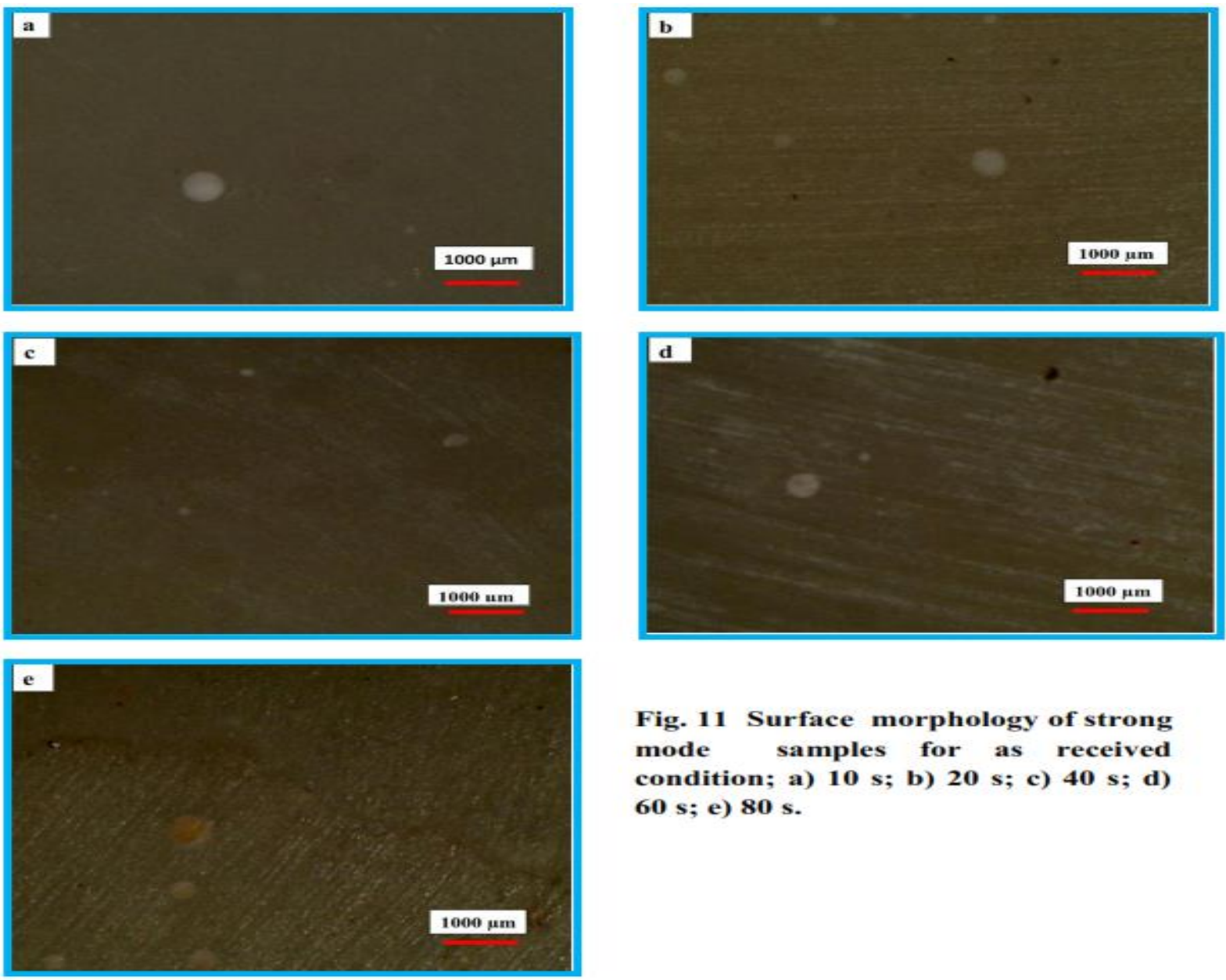

Fig. 11 Surface morphology of strong mode samples for as received condition; a) $10 \mathrm{~s}$; b) $20 \mathrm{~s}$; c) $40 \mathrm{~s}$; d) $60 \mathrm{~s}$; e) $80 \mathrm{~s}$. 
Vol. 39, No. 1. January 2020

\section{CONCLUSIONS}

From the present study on the hybrid composite resin and nanocomposite resin, the following conclusions can be drawn:

1. Wear decreases with increasing polymerization time at all normal loads used for as received group.

2. Wear first increases and then decreases with increasing the normal load for all

tested samples.

3. The hybrid composite containing 0.1 wt. $\% \mathrm{TiO}_{2}$ nanoparticles appears to exhibit significantly higher wear resistance compared to the hybrid composite containing 0.2 and $0.3 \mathrm{wt}$. $\% \mathrm{TiO}_{2}$ nanoparticles as well as unfilled composites with no $\mathrm{TiO}_{2}$ nanoparticles.

4. Polymerization time, normal load and $\mathrm{TiO}_{2}$ nanoparticles content have significant influence on the wear results of the tested composite resin.

\section{REFERENCES}

1. Powers J. M., Douglas W. H. and Craig R. G., "Wear of Dimethacrylate Resins Used in Dental Composites", Wear, Vol.54 ,pp. 79 - 86, (1979).

2. Liqun C., Xinyi Z., Xu G., Shouliang Z., "An in Vitro Investigation of Wear Resistance and Hardness of Composite Resins, Int J Clin Exp Med,Vol. 6, No. (6), pp. 423-430,( 2013).

3. Witold B. , Vera K. , Domagoj V.and Jenna W., "Tribology of Polymers and PolymerBased Composites", Journal of Materials Education, Vol.32, No. (5-6), pp. 273 290,(2010).

4. Yanni T., Yong L., Liam M. Grover, Baiyun H., "Wear Behavior of Light Cured Dental
Composites Filled with Porous Glass-Ceramic Particles", Journal of the mechanical behavior of biomedical materials, Vol. 3,pp. $77-84$, (2 01 $0)$.

5. Ibrahim M. Hamouda, HagagAbd Elkader, "Evaluation the Mechanical Properties of Nanofilled Composite Resin Restorative Material, Journal of Biomaterials and Nanobiotechnology, Vol. 3, pp. 238-242, (2012).

6. Ayman A. Aly, El-Shafei B. Zeidan, AbdAllah A. Alshennawy, Aly A. El-Masry, Wahid A. Wasel, "Friction and Wear of Polymer Composites Filled by Nano-Particles", World Journal of Nano Science and Engineering, Vol. 2, pp. 32-39,(2012).

7. Rymuza Z., "Tribology of Polymers", Archives of Civil and Mechanical Engineering, Vol. VII, No. (4), pp. 177- 184,(2007).

8. ASM International, ASM Handbook Volume 18, "Friction, Lubrication, and Wear Technology", American Society for Metals, Metals Park, Ohio, pp. 341-347, (1992).

9. Nuruzzaman, D.M., Chowdhury, M.A., and Rahaman, M.L. "Effect of Duration of

Rubbing and Normal Load on Friction Coefficient for Polymer and Composite Materials", Industrial Lubrication and Tribology, Vol. 63, pp. 320 - 326,( 2011).

10. Ramadan M. A., Abu Elainin H. M., Mazen A. A., Ali W. Y., "Abrasive Wear of Teeth", Journal of the Egyptian Society of Tribology Vol. 8, No. 2, April 2011, pp. 56 - 66, (2011). 11. Ramadan M. A., Ali W. Y. and Mazen A., "The Mechanical Wear of Teeth, Dental Wear", Lab Lambert Academic Publishing, ISBN: 9783-659-00089-8, US, (2012).

12. Lu H., Lee Y., OguriM, Powers J., "Properties of a Dental Resin Composite with a Spherical Inorganic Filler", Operative Dentistry, Vol.31, No. 6, pp.734-740, (2006).

13. Aljosa I., Tijana L., Larisa B., Marko V., Influence of Light-Curing Mode on the Mechanical Properties of Dental Resin 
Vol. 39, No. 1. January 2020

Nanocomposites, Procedia Engineering, Vol. 69, pp. 921 - 930, (2014).

14. Manhart J., KunzelmannK.H., Chen H.Y., HickelR., "Mechanical Properties and Wear Behavior of Light Cured Packable Composite Resins, Dental Materials, Vol. 16, pp. 33-40, (2000).

15. Agarwal G., Patnaik A., Sharma R. K.,'Parametric Optimization and Three-Body Abrasive Wear Behavior of Sic Filled Chopped Glass Fiber Reinforced Epoxy Composites", International Journal of Composite Materials, Vol. 3, No. (2), pp. 32-38, (2013).

16. Ramadan M. A., Abu Elainin H. M., Mazen A. A. and Ali W. Y., "Influence of Brushing Force on Abrasive Wear of Teeth", Journal of the Egyptian Society of Tribology Vol. 8, No. 4, October 2011, pp. $47-59$, (2011).

17. Chang L., Zhang Z., Breidt C. and Friedrich K., "TribologicalProperties of Epoxy Nanocomposites: I. Enhancement of the Wear Resistance by Nano-TiO2 Particles," Wear, Vol. 258, No. 1-4, pp. 141-148, (2004).

18. Meshref A. A., Mazen A. A., El-Giushi M. A. and Ali W. Y., "Effect of Curing Process of Dental Nanocomposite Resin on Shore Hardness , EGTRIB Journal,Vol. 13, NO. 2, pp. 25 37,(2016).

19. Hegde M. N., Hegde P., Bhandary S. , Deepika K., "An evaluation of compressive strength of newer nanocomposites: An in vitro study," Journal of Conservative Dentistry, Vol. 14, pp. 36-39, (2011).

20. Cai LiS., Na Li Y., "Journal of Applied Polymer Science", Vol. 116,pp. 2965 -2969, (2010). 


\title{
سلوك التأكل لحشوة الراتتج المركب المدعمة بحبيبات ثاني اكسيد التيتانيوم النانوية
}

\author{
مشرف ع. ع. ، ماذن أ. ع. ، الجيوشي م. ع. ، علي و.بي \\ قسم هنسة الانتاج والتصميم الميكانيكي، كلية الهنسة ، جامعة المنيا ، مصر
}

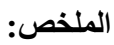

يهذف هذا البحث الي دراسة تاثير زمن التجفيف والاحمال العمودية و نسبة حبيبات ثاني اكسيد التيتانيوم النانوية علي سلوك التأكل لحشوة الراتتج المركب المملؤة بحبيبات ثاني اكسيد التيتانيوم النانوية. نم استخدام حشوة الراتتج المركب و حبيبات ثاني اكسيد التيتانيوم النانوية لتحقيق هذا الهدف. تم تجهيز أربعة مجموعات من العينات واحدة بدون حبيبات ثاني اكسيد التيتانيوم النانوية والثلاثة مجموعات الاخري تحتوي علي نسب مختلفة من حبيبات ثاني اكسيد التنتانيوم النانوية 0.1 و 0.2 و 0.3 \% بالوزن. عملية الخلط تمت يدويا ثم تم وضع الخليط في أسطمبة من البلاستيك ثم تم تجفيف العينات باستخدام جهاز التجفيف الضوئي من الطرفين لمدة 10 و 20 و 40 و 60 و 80 ثانية. ونت تحديد التأكل الحادث في العينات باستخدام اختبارالتأكل القطعي ثنائي الأجسام عند الظرف التالية: سرعة الانزلاق= 60 مشوارلكل دقيقة ،الحمل =6,8,10,12,14 نيوتن، زمن الاختبار = 60 ثانية. وجد أن التأكل يقل مع زيادة زمن التجفيف عند كل الاحمال المستخدمة .كما وجد أن التأكل يعتمد على الاحمال العمودية المستخدمة. كما تبين ان اضافه نسب كبيره من حبيبات ثاني اكسيد التيتانيوم النانوية فوق ( 0.1 \% بالوزن) الي حشوة الراتتج المركب تؤدي الي زيادة التأكل ، بينما اضافة نسب صغيرة من حبيبات ثاني اكسيد التيتانيوم النانوية اقل من ( 0.1 \% بالوزن) الي حشوة الراتتج المركب تحسن من مقاومة التأكل. تقترح الدراسة الحالية إلى أنه من أجل تقليل التآكل من المهم استخدام زمن التجفيف العالي نسبيًا و نسب صغيرة من حبيبات ثاني اكسيد التيتانيوم النانوية وقوة مضغ 